\title{
THE ADDIS SEDIMENT COUNT IN SCARLET FEVER ${ }^{1}$
}

\author{
By JOHN D. LYTTLE
}

(From the Babies Hospital and the Department of Pediatrics, College of Physicians and Surgeons, Columbia University, New York City)

(Received for publication August 9, 1932)

The following report deals with a study of the urinary changes in ordinary scarlet fever as revealed by the Addis sediment count technique. No cases of clinical postscarlatinal nephritis have been included. Particular interest centers in the period from 8 to 30 days after the onset of infection.

\section{LITERATURE}

As early as 1874 Mahomed (1) found that scarlet fever convalescents, at some period during the six weeks after defervescence, exhibited a pulse of high tension (sphygmograph) and hemoglobinuria (guaiac test) without albuminuria (nitric acid test). If the tension was high and persisted, albumin was liable to appear. Occasionally there was anorexia with slight fever $\left(100^{\circ} \mathrm{F}\right.$.) and sometimes a little edema was evident upon careful examination, but as a rule, there were no constitutional symptoms or signs. He called this picture the "prealbuminuric stage of nephritis."

Thompson (2), in 1886, examined the urine for blood and albumin three times a day for $\mathbf{5 6}$ days in $\mathbf{1 8 0}$ cases of scarlet fever. Eighty-four per cent of the patients were under 15 years. In 66 cases ( 37 per cent) there were no urinary changes. Two cases (1 per cent) showed anasarca without urinary changes, and in 112 (62 per cent) the urine showed albumin, blood, or both, with or without edema. Thompson calls all of these 112 cases "nephritis," but "in some cases, the evidence of kidney mischief was so slight and evanescent that but for careful and frequent testing, the presence of these substances, would no doubt, have been overlooked." Thompson also found, at times, a positive guaiac test with no albumin, but thought the "pre-albuminuric stage" of nephritis was infrequent.

Dittmar (3) examined the urine in 91 consecutive cases twice daily for 56 days. Eighty-five per cent of the patients were under 15 years. The nitric acid test for albumin and the guaiac test for blood were used. Forty-eight (52.7 per cent) of the cases at some period showed positive

1 Two patients were studied through the courtesy of Dr. Charles Hendee Smith and 12 patients were studied on the wards of Willard Parker Hospital with the co-operation of Dr. George W. Caldwell. 
tests for albumin, or blood, or both. He repeatedly found positive guaiac tests with negative albumin.

Caiger (4) found traces of albumin in the convalescent stage of scarlet fever occurring in from 30 to 40 per cent of cases. He examined the urine only twice a week and noted that in children it was not always possible to do so more regularly.

McCrae (5) analyzed 1,034 cases over a period of seven years and found urinary disturbance subsequent to the fall of fever in 25 per cent. Five per cent showed definite nephritis, but only 2 per cent presented physical signs and symptoms of nephritis. The frequency of testing and methods used are not mentioned.

Koch (6) observed a definite increase in blood pressure in every case of scarlet fever from the 14th to the 20th day. During this period of hypertension, he found albuminuria, and less frequently, erythrocytes and casts (at times in only a single specimen, and not invariably in every case).

Hirschberg and Ssucharewa (7) have reported more recently on 845 cases of scarlet fever studied over a period of eight years. Ninety-two per cent were under 12 years. The incidence of nephritis was 20 per cent, but they include a large number (56, or 33.5 per cent of the total) of cases where there were no symptoms and where the urinary changes were slight and did not persist. They cite as a typical case in this group a child with no extrarenal symptoms whose urine showed a trace of albumin on the 21st day and an occasional red cell in the sediment for the two subsequent days.

$\operatorname{Ker}(8)$ stated that it is not unusual to find tube casts in cases of very slight and transient albuminuria. The complication tends to occur at the period of convalescence when acute nephritis is most apt to present itself.

\section{METHODS AND NORMAL STANDARDS}

The technique described by Addis was followed for the counting of casts and cells and that of Shevky and Stafford for the quantitative estimation of protein. Methods and minor modifications in the procedure when applied to children have been described in a previous paper (9).

We have tentatively set the following normal standards from a study of 161 counts on 74 normal children aged 4 to 12 :

The upper limit of normal excretion per 12 hours in children from 4 to 12 years of age

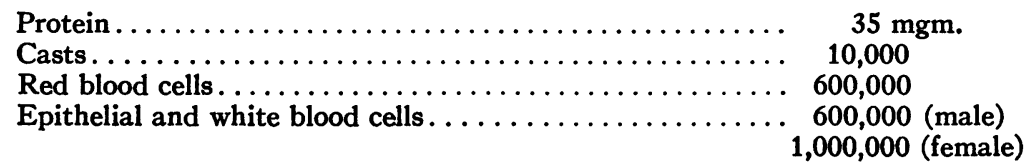




\section{OBSERVATIONS IN SCARLET FEVER}

Sediment counts were done three times a week for thirty days (in a few cases longer) on 14 cases of scarlet fever. The patients selected were all males from 4 to 14 years of age and remained in bed during the entire period on a low protein, salt-poor diet. One patient (number 2) had had scarlet fever seven years previously and another (number 1) had had an attack of acute glomerular nephritis following tonsillitis (hemolytic streptococcus) a year earlier. None of the patients developed the typical signs and symptoms of postscarlatinal nephritis.

The following clinical observations seem pertinent:

Temperature. In two cases fever persisted to the 9th and 12th days respectively: in two others it continued to the 6th day. In the rest the temperature was normal by the 4 th day or sooner. Transient rises in temperature after the first week were observed in three instances.

Complications. There were no cardiac or arthritic complications. Two cases presented a mild cervical adenitis. One patient had an unexplained fever on the 23rd day, and another patient developed a bilateral otitis with streptococcus hemolyticus cultured from the discharge.

Scarlet fever antitoxin. Five patients received from 2,000 to 12,000 units of antitoxin before the 5 th day of the disease. Serum reactions were observed on the 6th, 7th, 8th, and 9th days following the injections. In four of these cases there were slight abnormalities in the sediment count during the serum reaction. Analogous changes have been observed in serum sickness following diphtheria and meningococcus antitoxin. It is important to note that the patients who received antitoxin and suffered from serum sickness did not show at a later date sediment count abnormalities different from those presented by patients who received no serum.

The individual cases are presented graphically in Charts 1, 2, 3, 4 and 5.

Urinary studies were not made during the first seven days in two cases; with two exceptions the remaining twelve showed some increase in protein, cast and cell excretion during that period. This was interpreted as the "toxic albuminuria" which occurs during the febrile stage of any acute infection. The etiology and pathogenesis of "toxic albuminuria" are not known, yet it seems reasonable to believe that the urinary changes occurring during the febrile period of invasion of an acute infection must have a different origin and interpretation from those which take place in the afebrile period some two or three weeks after the acute onset.

During the period from 8 to $\mathbf{4 5}$ days after onset all cases showed in varying degree increases in the excretion of protein, casts and cells. The highest levels reached were: for protein-174 mgm.; for casts-1,320,000; for red blood cells-12,915,000; for epithelial and white blood cells$9,460,000$. The increases were irregular and explosive in character. Protein, cast and cell excretion rose and fell together at times but just as 
often increased protein excretion was accompanied by normal cast and cell excretion and vice versa. As counts were not done daily, we have no accurate information as to the duration of these flare-ups. The charts

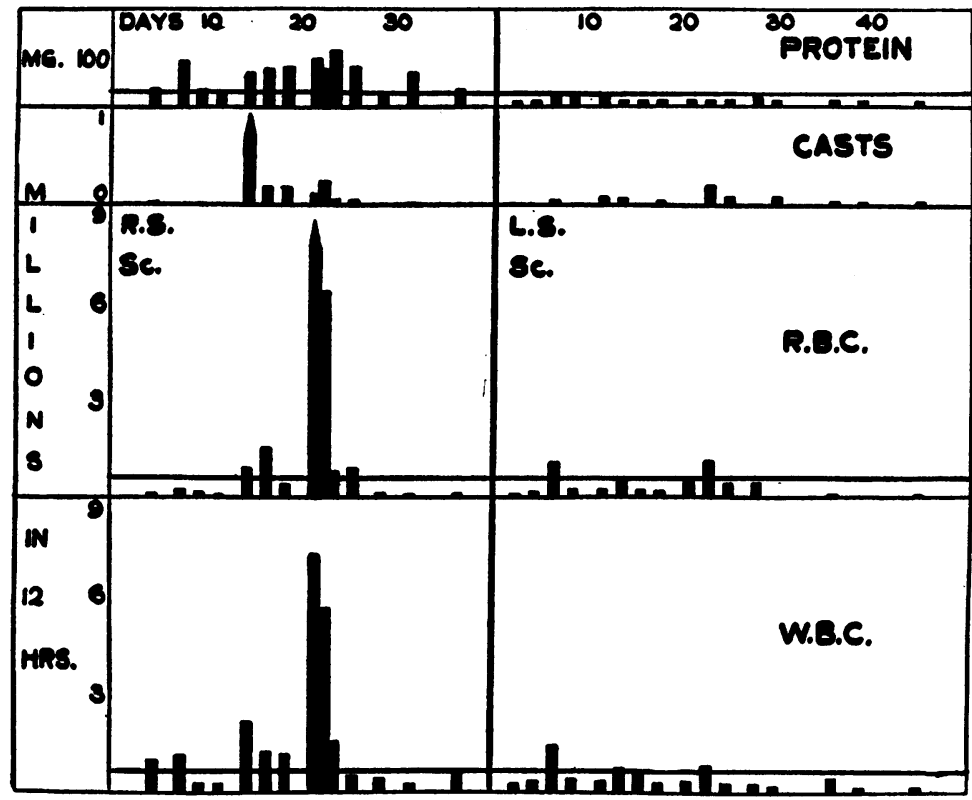

Chart I

R. S., 14 years old. Scarlet fever mild. Temperature normal fourth day, no complications.

L. S., 6 years old. Scarlet fever mild. Temperature normal sixth day, no complications. Had acute glomerular nephritis one year before.

The light lines above the base lines represent the upper normal limits: for protein $35 \mathrm{mgm}$., for red and white blood cells 600,000 . Any cast count that appears on the chart is abnormal, i.e., above 10,000 .

of the individual cases show that flare-ups lasting 2 to 4 days were followed by normal or nearly normal counts for 2 to 6 days, when another brief rise occurred followed by a normal period. In two cases there were three such rises.

There were no serious complications in the group. In the four cases that had otitis, unexplained fever or adenitis, the changes during the acute phase of these complications were no more marked than in the uncomplicated cases.

\section{DISCUSSION}

It is difficult and perhaps not important to draw any definite line between these sub-clinical changes and true postscarlatinal nephritis. Except for red cell excretion the higher figures might be found in a mild case of acute nephritis. Red cell excretion in an ordinary hospital case of nephritis is usually in the hundreds of millions. As Addis (10) points 
out, glomerulonephritis is often a symptomless disease at onset. In our experience in children, edema, hypertension and nitrogen retention are not the rule. For Addis (11), whose definition of nephritis is based on a

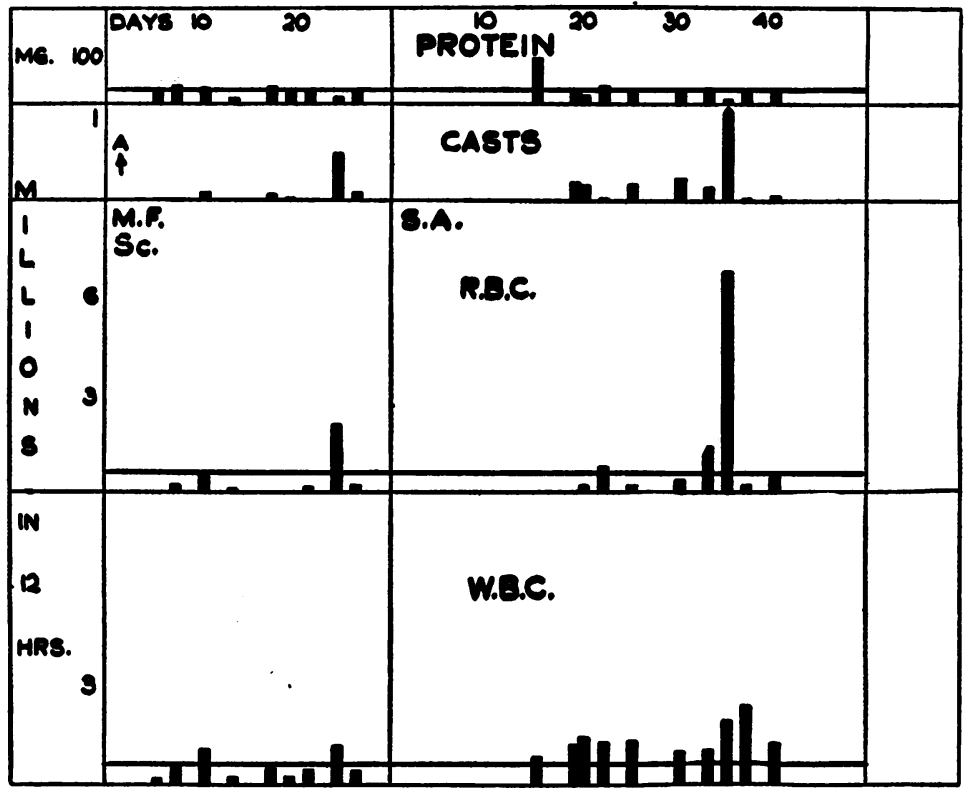

Chart II

M. F., 7 years old. Moderately severe scarlet fever. Scarlet fever antitoxin 15,000 units on the second day, serum sickness on the eleventh day. No complications.

S. A., 5 years old. Mild scarlet fever. Had adenitis on admission which subsided by the seventeenth day. On the thirty-sixth day definite increase in casts, red and white cells and temperature $100.5^{\circ} \mathrm{F}$. for a few hours.

The light lines above the base lines represent the upper normal limits: for protein $35 \mathrm{mgm}$., for red and white blood cells 600,000 . Any cast count that appears on the chart is abnormal, i.e., above 10,000 .

quantitative increase above the normal excretion of protein, casts and cells, these changes would represent nephritis. McCrae (5) notes that in four-fifths of his cases of well marked nephritis, the diagnosis depended entirely on the urinary examinations. Pospischill (12) speaks of an abortive course of nephritis in which only one or a few urinary specimens become hemorrhagic, so that, clinically, the nephritis lasts only a few hours. Caiger (4) believes that "although changes in the renal tissue are by no means necessarily present in an ordinary attack of scarlatina, yet simple albuminuria of any degree and acute nephritis, when they supervene, are due essentially to the same morbid process, varying simply in intensity, or in the vulnerability of the kidney in the particular subject." He supports his view by the following clinical observations: 
the relative prevalence of simple albuminuria and acute nephritis in any particular outbreak; their tendency to appear under the same environmental conditions (deficient ventilation, overcrowding); their common

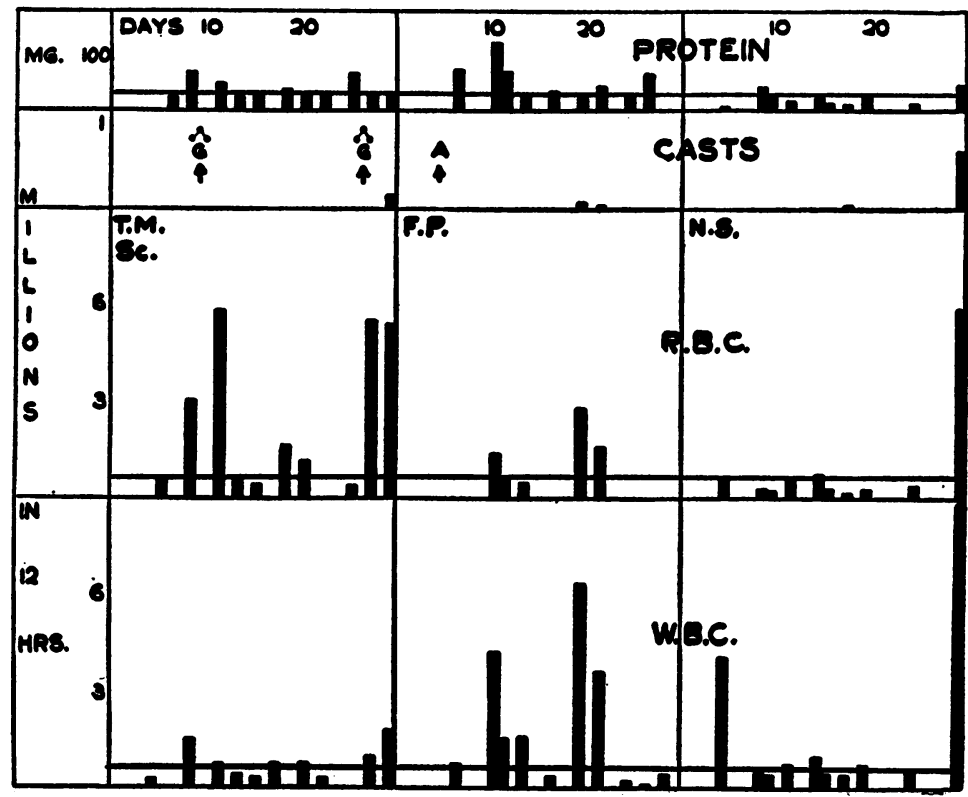

Chart III

T. M., 14 years old. Mild scarlet fever. Seventh to eleventh days cervical adenitis, temperature $100^{\circ}$ to $102^{\circ} \mathrm{F}$. Exacerbation of adenitis twenty-seventh and twenty-eighth days with temperature $100^{\circ}$ to $102^{\circ} \mathrm{F}$.

F. P., 14 years old. Moderately severe scarlet fever. Temperature normal tenth day. Scarlet fever antitoxin 10,000 units on the fifth day, serum sickness on the thirteenth day. No complications.

N. S., 4 years old. Mild scarlet fever. Temperature normal on the fifth day. No complications.

The light lines above the base lines represent the upper normal limits: for protein $35 \mathrm{mgm}$., for red and white blood cells 600,000 . Any cast count that appears on the chart is abnormal, i.e., above 10,000.

tendency to develop at the same stage of the illness. The age liability is also in agreement, that is, the susceptibility to either affection is fairly constant from the second year to the fifteenth. Ker (8) says: "It is hard to resist the conclusion that the difference between the two conditions (late albuminuria and true nephritis) is only one of degree."

For purposes of discussion we have used the terms "renal irritation" or "micro-nephritis," but until there is a better definition of nephritis, it is immaterial what name is applied. The important points are that in 14 cases of scarlet fever there appeared in the urine in slight degree the qualitative changes that are found in nephritis, and that these changes 
occurred at the time we expect postscarlatinal nephritis to develop. A study of the literature indicates that these changes take place in a great majority of cases of scarlet fever.

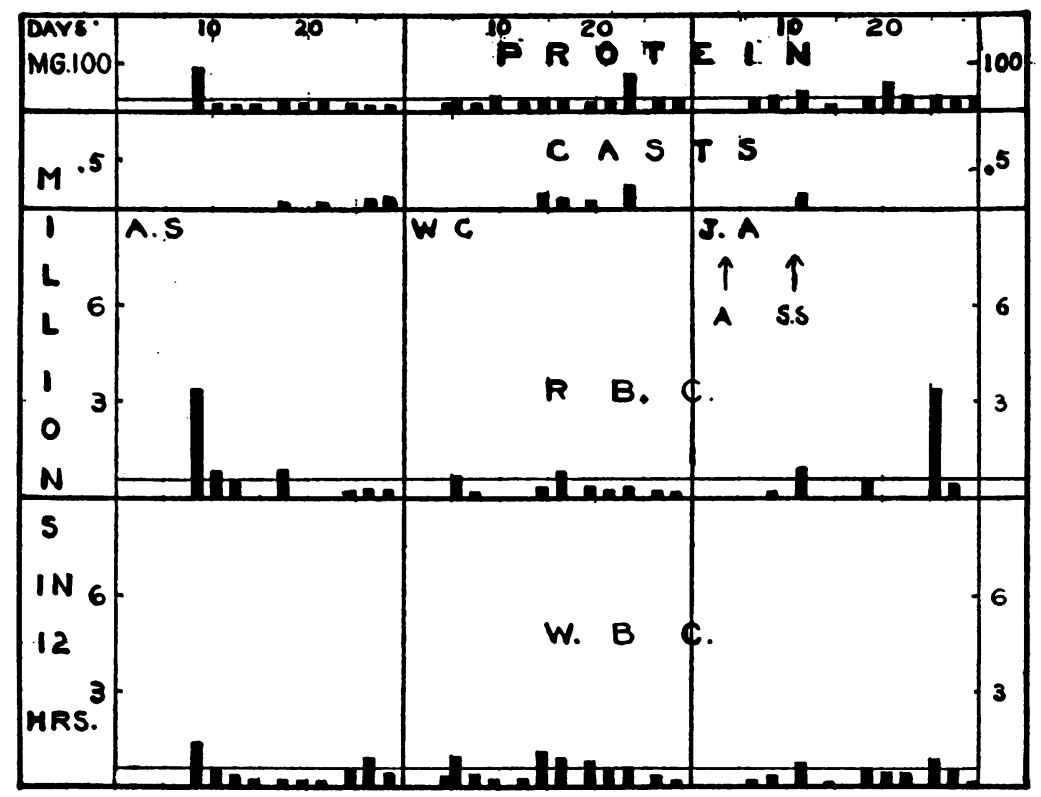

Chart IV

A. S., 7 years old. Mild scarlet fever, afebrile throughout, no complications.

W. C., 9 years old. Mild scarlet fever, temperature normal 3d day.

J. A., 7 years old. Moderately severe scarlet fever, temperature normal 6th day, 5,000 units scarlet fever antitoxin on 4th day, serum sickness without temperature on 11 th day.

The light lines above the base lines represent the upper normal limits: for protein $35 \mathrm{mgm}$., for red and white cells 600,000 . Any cast count that appears on the chart is abnormal, i.e., above 10,000 .

We have no data to present concerning the mechanism of the urinary changes we are reporting. Evidence is accumulating which points to the view that the development of postscarlatinal nephritis is concerned in some way with the immunological reactions of streptococcus hemolyticus. Escherich and Schick (13) first drew attention to the analogy between nephritis and the group of allergic reactions and suggested that "it might be a case of hypersensibility of the organism which is expressed in the ability of small amounts of pathogenic substance to awaken clinical symptoms which at another time would be tolerated without any reaction." More recently this idea has been elaborated by Friedemann and Deicher (14) and by Longcope (15). Since the sub-clinical changes we have observed occur at the same time that true nephritis develops and are qualitatively the same as those found in nephritis, it seems likely that the 

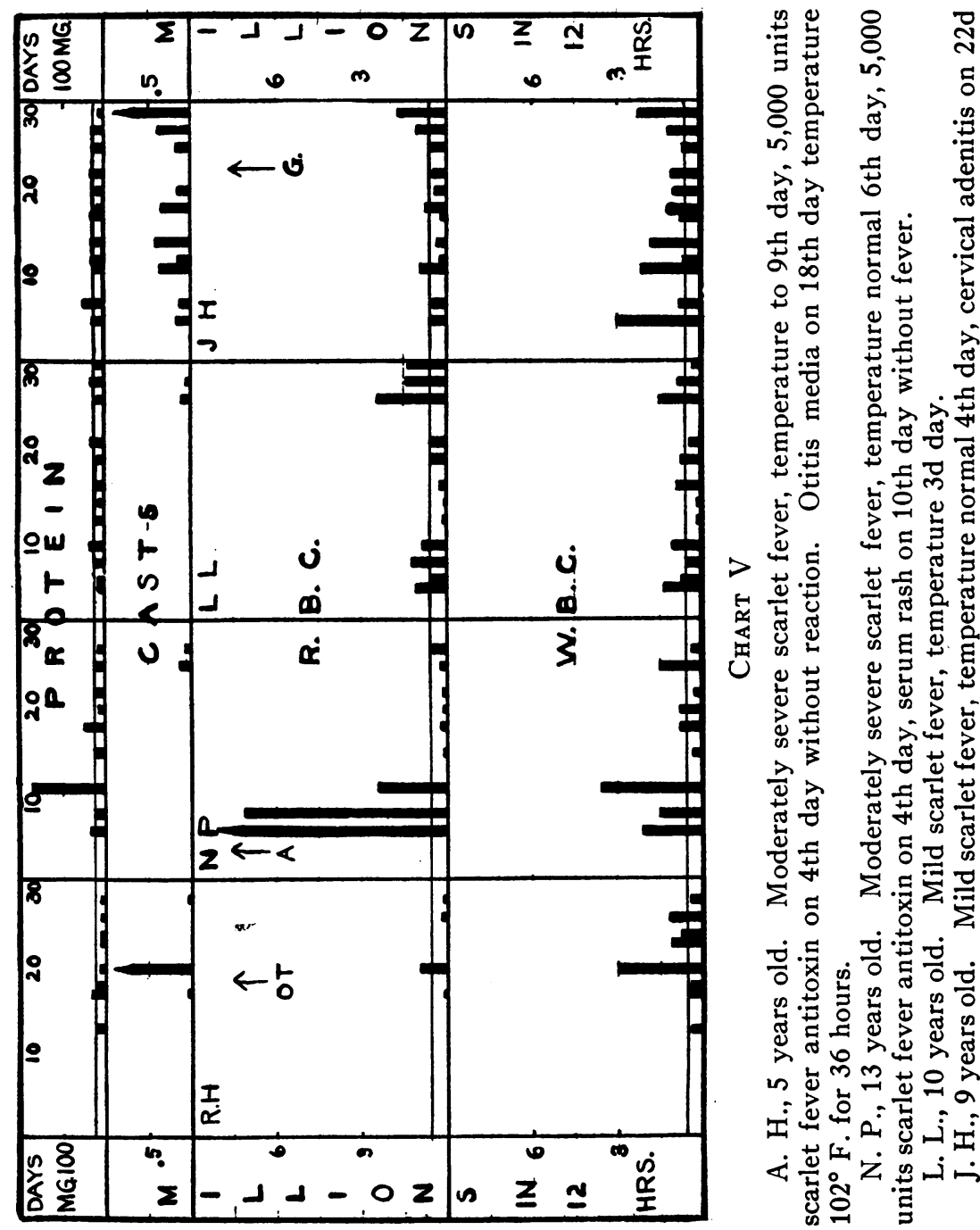

غُ

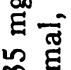

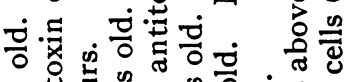

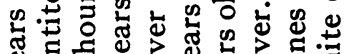

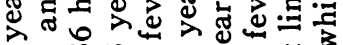
in

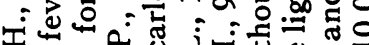

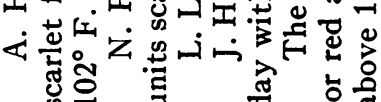


same mechanism is at work in both conditions. Our observations and a study of the literature indicate that the majority of individuals who contract scarlet fever make a satisfactory immunological adjustment in the postfebrile period. Kidney damage is slight, shown only by unusually careful examination of the urine; the nephritis is aborted. A few individuals are unable to make this adjustment and develop true postscarlatinal nephritis.

Studies shortly to be published indicate that similar urinary changes occur in children who are infected with streptococcus hemolyticus and streptococcus viridans and in those with an active rheumatic infection, whereas, they occur infrequently in children with pneumococcus infection.

\section{SUMMARY}

1. The technique of Addis for the quantitative mensuration of protein, casts and cells in the urine has been applied to 14 cases of scarlet fever. All cases showed moderate transient increases in the excretion of protein and formed elements during the period from 8 to 45 days after onset of scarlet fever.

2. The relation of these changes to true postscarlatinal nephritis is discussed.

\section{BIBLIOGRAPHY}

1. Mahomed, Fred A., Medico-Chirur. Tr., Series II, 1874, xxxix, 197. The Etiology of Bright's Disease and the Prealbuminuric Stage.

2. Thompson, R. S., Medico-Chirur. Tr., Series II, 1886, li, 97. Scarlatinal Albuminuria and the Pre-Albuminuric Stage Studied by Frequent Testing.

3. Dittmar, F., Glasgow M. J., 1897, xlviii, 426. Scarlatinal Albuminuria.

4. Caiger, F. F., Allbutts System of Medicine, 1901, ii, 122. Scarlet Fever.

5. McCrae, John, Tr. A. Am. Physicians, 1913, xxviii, 194. The Incidence of Nephritis after Scarlet Fever.

6. Koch, F., Ztschr. f. klin. Med., 1925, cii, 182. Klinische Beobachtungen bei Scarlachnephritis.

7. Hirschberg, B. S., and Ssucharewa, M. E., Jahrb. f. Kinderh., 1929, cxxii, 340. Clinical Picture of Post-Scarlatinal Nephritis.

8. Ker, C. B., Infectious Diseases, London, 1929. 3rd ed.

9. Lyttle, John D., J. Clin. Invest. 1933, xii, 87. The Addis Sediment Count In Normal Children.

10. Addis, T. A., Bull. Johns Hopkins Hosp., 1931, xlix, 203. Haemorrhagic Bright's Disease. I. Natural History.

11. Addis, T., and Oliver, J., The Renal Lesion in Bright's Disease. Hoeber, New York, 1931.

12. Pospischill. Quoted by Schick. Escherich and Schick, Der Scharlach, Vienna, 1912.

13. Escherich, T., and Schick, B., Der Scharlach, Vienna, 1912.

14. Friedemann, U., and Deicher, H., Ztschr. f. klin. Med., 1928, cviii, 737. Weitere klinische und experimentelle Untersuchungen über den Scharlach. XII. Die Pathogenese der Scharlachnephritis.

15. Longcope, W. T., Bull. Johns Hopkins Hosp., 1929, xlv, 335. The Pathogenesis of Glomerular Nephritis. 